\section{Recommendations of the College*}

The views of the College have been requested in anticipation of the decision of the European Court of Human Rights. The Special Committee of Council has considered the changes in the present legislation that would be appropriate in the light of the Commission's decisions.

1. Restricted patients must have the opportunity of access to a judicial body. It was considered that neither the Divisional Court of the Queen's Bench Division of the High Court, nor the Crown Court would be appropriate to deal with the specialized, sensitive and difficult issues which these cases would pose. It is, however, important to reassure Crown Court Judges that they may safely make restriction orders without fearing that dangerous patients will be lightly set at liberty. Equally, psychiatrists, particularly in Special Hospitals, should have confidence, as far as possible, in the new procedures.

2. It is considered that Mental Health Review Tribunals should be strengthened by appointing Judges or Recorders to act as chairmen (with powers to operate a judicial procedure for Restriction Order cases). The strengthened Tribunals would also deal with all other applications as at present.

3. A restricted patient should have a periodic right to appeal to the Tribunal against continued detention on the grounds that his case does not continue to fulfil the requirements for detention under Part V, Section 60 (a) (i) and (ii) of the

These recommendations of the Special Committee of Council on the Review of the Mental Health Act were approved by Council at its meeting on 16 June 1981, when approval was also given to the College's Recommendations for Mental Health Commissions (Bulletin, July, page 132).
Mental Health Act 1959. To justify continuing the detention the Tribunal would have to be satisfied that the patient was suffering from one of the four forms of mental disorder and that it was of a nature or degree that warranted the detention of the patient in hospital for medical treatment. The Tribunal would consider the dangerousness of the patient in relation to evidence supporting the opinion that the patient fulfils the other criteria.

4. The Tribunal should be empowered to discharge a patient absolutely if it is satisfied that there are no continuing grounds to detain him.

5. In cases where there is conflicting medical opinion, or where there are no grounds to continue the detention, although there is continuing evidence of mental disorder, the Tribunal would have the power to order a conditional discharge to operate once appropriate arrangements are made.

6. The Tribunal would have a further option, where appropriate, to order the removal of restrictions under Section 65 , the patient remaining in hospital subject to Section 60 of the Act.

7. Recalled conditionally discharged patients should have the right to have the recall speedily reviewed by a Tribunal.

8. The Home Secretary would cease to have the authority to reject a Tribunal's decision, but should have the right of appeal against a Tribunal decision to a higher Court, within a specified period of time, during which the Tribunal's decision would not be put into operation (following notice of intention to appeal).

The College's concern in making these recommendations is to promote a procedure which would have the confidence of all concerned, but which would not lead to any mentally disordered patients being inappropriately sentenced to imprisonment.

\title{
Divisional Activities
}

\section{South-Western Division}

A few years ago this Division took a critical look at its biannual meetings, and what we saw was too often disappointing. We decided to set about improving the organization, and the social and scientific quality of the meetings.

The Spring meetings have been extended by two sessions on concurrent days, with dinner and jollification for members and guests in their overnight hotel in attractive places. Each session has become a mini-symposium, the subject being agreed after discussion by the Executive Committee. Where appropriate, outside experts have been invited to attend as guests and contribute papers. A long period is formally allocated for general discussion, and this has proved to be one of the most obviously appreciated changes.
The Autumn meetings have remained one-session affairs, but the habit of scrutiny by the Executive Committee seems to have stimulated local organizers, because there has been a sustained improvement in the quality of papers and organization.

Consultant members have been regularly reminded to encourage their trainees to attend; and those who have passed the Membership Examination in the past year are invited as guests to the Spring meeting. Trainees have also been invited to present papers. There has been some increase in trainees' attendance, but interestingly mainly of senior trainees, and some of them have been heard to allow that there may be more to the College than the Yellow Journal!

The results of the changes have been larger attendances and more participation from the floor. The social element 
has allowed us to get to know something more than the faces of each other. This can only be helpful in developing a force of community interest in College and NHS affairs.

The past year has been especially notable for its two meetings, both firsts. The Spring meeting in 1980 was held at the Postgraduate Centre of the General Hospital at St Helier in Jersey. The Channel Islands come under the South Western Division, and the Division hoped for some time to hold one of its meetings there. The Division is grateful to $\mathrm{Dr}$ Gwynn Evans for his invaluable help in making the meeting possible. One hundred and twenty-ight members and spouses travelled to Jersey in two parties, using Sealink's very economical package.

The meeting opened with a symposium on suicide and attempted suicide, with contributions by Professor Gethin Morgan, University of Bristol, Dr Yvonne Wiley, Bristol, Dr Vorster of Plymouth and Dr Lumsden Walker of Bristol, whose paper was read in his absence by Dr Martin Gay. Dr David Spenser, Consultant Pathologist in Jersey, contributed a very interesting paper to this symposium, giving a detailed account of all the suicides and possible suicides, that had occurred in Jersey over a two-year period.

This was followed by a symposium on psychotherapy where the critique was presented by Dr Ian Christie of Knowle Hospital, and the apologia by Dr Irving Kreeger of the Institute of Psychiatry.

A third working session was devoted to the Membership Examination. It was introduced by Dr Thomas Bewley, the College Dean, and this was followed by a paper from two trainces, Dr Carol Trotter, University of Southampton, and Dr Gareth Hughes of Bristol, who outlined their own personal experiences and presented the results of a survey of trainces they had undertaken in the Division. This paper has since been published in the Bulletin (January, 1981, p. 8).

The final session was opened by Professor Poilpre of the University of Caen, who gave an outline of the organization and practice of psychiatry in France. The final paper was read by a Past President of the College, Professor Linford Rees, who gave a very comprehensive review of British psychiatry today with some interesting glimpses into the future.

Those present were unanimous in thinking that the meeting had been a memorable one, to which no doubt the setting, the weather, the hospitality and the quality of the speakers and their presentation all contributed.

The Autumn meeting was held at Princess Alexandra's Royal Air Force Hospital at Wroughton, near Swindon. This is believed to be the first time that the Division has met at an Air Force Hospital. It has met in the past at Netley and also at Haslar.

Members were welcomed to the hospital by the Commanding Officer, Air Commodore Risley-Pritchard, who gave an account of the history of the hospital which was built in the late 20's and during the war was an important link in the evacuation chain from France. It is now the centre for neuro-psychiatry in the RAF. Neuro-psychiatry as practised in the RAF was then described by Group Captain Black.

He pointed out that Air Force psychiatry was organically orientated and the main function of psychiatrists was to support aircrew in their fighting role. Group Captain Johnson gave a paper on alcoholism in the Air Force, and this was followed by a paper by Group Captain Anthony and Squadron Leader Fowler on community psychiatry. They both described individual projects they had undertaken and produced an assessment of these projects. It seemed clear from the figures presented that active community psychiatry substantially cuts down hospital admissions.

\section{DAvirs}

Homorary Secretary

\section{Irish Division}

The Spring Quarterly Meeting of the Irish Division took place at the Psychiatric Unit, Letterkenny General Hospital, Co. Donegal. The Clinical Programme consisted of two papers. The first paper was on behavioural psychotherapy as applied by nurse therapists; two case presentations were detailed by nurses from St Conal's Hospital. The second paper, presented by a multidisciplinary team from St Conal's Hospital, outlined their experiences in treating alcoholism over the past year. Both papers provided much discussion and various members drew attention to the growing problem of alcoholism in the Republic of Ireland.

The Business Meeting was informed that the Division had met the Minister of Health and his officials to discuss the new Mental Health Services Bill 1980. Reference was made to certain important amendments passed at the Committee stage of the Bill in Dail Eireann. The Chairman informed the membership that the Department of Health had agreed to have regular meetings with a delegation from the Division. Professor Lynch also stated that a working party of the Executive was preparing a document on conditions in Irish psychiatric services.

The members expressed their appreciation to Dr M. P. Lawlor, Chief Psychiatrist, Letterkenny, for hosting the meeting.

David Shanley

Honorary Secretary

\section{East Anglian Division: 1980-81}

The Division has held scientific and general business meetings in September 1980 and March 1981. The September meeting was held at Churchill College in Cambridge, and the Royal Free Hospital, Hampstead, was host for the meeting in March 1981. Both of those were certainly very enjoyable and the papers were brisk and informative. 